\title{
Children's Rights when Financing Development through Multilateral Development Banks: Mapping the Field and Looking Forward
}

\author{
Gamze Erdem Türkelli \\ Law and Development Research Group, Faculty of Law, University of \\ Antwerp; Post-Doctoral Fellow Fundamental Research No: Research \\ Foundation Flanders (FWO), Antwerp, Belgium \\ gamze.erdemturkelli@uantwerpen.be
}

\begin{abstract}
Children and their rights are increasingly recognised as an integral part of the global development agenda as set out by the 2030 Agenda and the accompanying SDG S (Sustainable Development Goals). UN Human Rights Council Resolution 34/16 calls for a child rights-based approach to implementing these goals. Aspirations aside, children's rights are largely invisible when the debates shift to how development is financed. Consequently, a children's rights-based inquiry into the governance of institutions that finance development, is largely absent. This article seeks to overcome the relative scarcity of critical academic reflection on how and to what extent children's rights feature in how development projects are financed by multilateral development banks (MDBs). The article first identifies common strands in norms MDB s use to govern themselves, their clients and borrowers. It then proceeds to situate how children's rights fit into these administrative governance frameworks and goes on to address future perspectives of engagement to address shortcomings.
\end{abstract}

\section{Keywords}

children's rights - sustainable development - finance - World Bank - global administrative law - obligations 


\section{Introduction: Development, Finance and Children's Rights ${ }^{1}$}

The Convention on the Rights of the Child (CRC) broadly recognises that children's wellbeing and their ability to fulfil their developmental potential is linked to their living conditions and the resources at their and their parents' disposal. Parties to the CRC have a legal obligation to 'undertake all appropriate legislative, administrative, and other measures for the implementation of the rights' contained in the CRC under art. 4 (UN, 1989: Article 4). Of course, the ability of States Parties to do so may be constrained by the maximum available resources at their disposal and necessitate that States engage in international cooperation under art. 2 CRC. The Preamble of the CRC points to the significance of international cooperation in improving living conditions of children, particularly in developing countries. Achieving the full enjoyment of human rights through improved living conditions has been a central concern, not only of human rights law but also of the global development agenda. In fact, the post-World War II world witnessed the parallel but largely unlinked rise of the human rights movement and the development movement. Major economic institutions to lead the post-war reconstruction and development efforts, most notably the World Bank (шв) and the International Monetary Fund, were being set up during roughly the same period that the Universal Declaration of Human Rights was being drafted. In the largely separate worlds of development financing and human rights, separate agendas were pursued for a long time. Coupled with the realities of the Cold War, when championing human rights meant very different things to policy-makers in the Western and Soviet Blocs, development as pursued by international financial institutions in the West and those set up in other regions but based on the same Western model, such as the Asian Development Bank (ADB), the Interamerican Development Bank (IDB) and the African Development Bank (AfDB), remained macroeconomic. Regional development banks complemented the wB and focused on the macroeconomic development of their eponymous regions.

1 The preliminary research for the paper was undertaken in the context of a broader doctoral project on children's rights, business and financial institutions. That research project was funded under the Dосрко scheme of the University of Antwerp Special Research Fund (Bijzondere Onderzoeks Fonds - BOF) and benefited from the guidance and comments of Wouter Vandenhole, Koen De Feyter, Nicola Jägers as well as Daniel Bradlow, David Kinley, Radu Mares, Olga Martin-Ortega, Celine Tan and Stef Vandeginste. An earlier version of this paper was workshopped at the Law and Development Research Network (LDRn) Early Career Researchers Publication Workshop in March 2019 in Antwerp. I would like to particularly thank Siobhán Airey, John Harrington and Tine Van Hof for their very useful comments on that earlier version. 
The two separate agendas moved closer together during the 199os, coinciding with post-Cold War realities, when development shifted its focus from purely economic to more human, thus bringing the human rights and development agendas closer together. This period ushered in the Human Development Index, developed by the late Pakistani economist and development theorist, Mahbub ul Haq, who advocated that the concept of development as was evaluated and benchmarked at the international level should not only cover macroeconomic indicators but also a range of indicators that could demonstrate how and if economic development improved human lives (Ul Haq, 1995). To bridge the gap between this human-centred vision which had by then become central to the UN institutions, and the work of development banks, Ul Haq called on 'the World Bank and the regional development banks ... to descend from their macroeconomic concerns with national income accounts and production planning to human development issues' (Ul Haq, 1995: 10). The Human Development Report released by the UNDP in 1995, when this plea was published, tackled many issues at the core of children's rights such as education, food and nutrition, health (infant mortality rates, immunisation rates) and others (UNDP, 1995: 10-15).

At the turn of the millennium, three of the eight Millennium Development Goals (MDGs) tackled issues directly linked to children's rights: achieving universal primary education (MDG 2), reducing child mortality (MDG 4) and improving maternal health (MDG 5). Other MDGS on eradicating extreme poverty and hunger (MDG 1), promoting gender equality (MDG 3), combating HIV/AIDS, malaria and other diseases (MDG 6) and ensuring environmental sustainability (MDG 7) also had children's rights aspects.

The 2030 Agenda for Sustainable Development and the Sustainable Development Goals (SDGs) also contain various targets linked to children's rights and wellbeing but shy away from mentioning children's rights as such. The goals and targets directly mention children are:

\begin{tabular}{lcl}
\hline SDG & Target & Goal \\
\hline 1-No Poverty & 1.2 & $\begin{array}{l}\text { reduction of the proportion of children (as } \\
\text { well as adults) living in poverty } \\
\text { ending malnutrition especially by achieving } \\
\text { internationally agreed targets with regard to } \\
\text { stunting and wasting of children under five } \\
\text { years of age }\end{array}$
\end{tabular}




SDG Target Goal

3-Good Health \& $\quad 3.2 \quad$ ending preventable deaths of newborns and

\section{Wellbeing}

4-Quality Education 4.2

4- Quality Education 4.5

4- Quality Education 4.6

4-Quality Education 4.a

5-Gender Equality $\quad 5 \cdot 3$

8 - Decent Work and 8.7 Economic Growth

11 - Sustainable Cities 11.2 \& Communities

11 - Sustainable Cities 11.7

\& Communities children under 5 years of age, reducing neonatal mortality and under-5 mortality Provision of access to quality early childhood development, care and pre-primary education for all boys and girls

Elimination of gender disparities in education and guarantee of equal access to education for children in vulnerable situations (and others who are vulnerable such as persons with disabilities, indigenous peoples) Ensuring youth (and adult) literacy and numeracy

Building and upgrading of child, disability and gender sensitive education facilities and safe, non-violent, inclusive and effective learning environments

Elimination of all harmful practices, such as child, early and forced marriage and female genital mutilation

Eradication of forced labour, end modern slavery and human trafficking; prohibition and elimination of the worst forms of child labour, including recruitment and use of child soldiers;

Ending child labour in all its forms by 2025 Special attention to children (among other groups) in the provision of access to safe, affordable, accessible and sustainable transport systems for all and in improving road safety, notably by expanding public transport Provision of universal access to safe, inclusive and accessible, green and public spaces for children (as well as women, older persons and persons with disabilities) 


\begin{tabular}{lll} 
SDG & Target & Goal \\
\hline $\begin{array}{l}\text { 16-Peace, Justice \& } \\
\text { Strong Institutions }\end{array}$ & $\mathbf{1 6 . 2}$ & $\begin{array}{l}\text { Ending abuse, exploitations, trafficking and } \\
\text { all forms of violence against and torture of } \\
\text { children }\end{array}$ \\
$\begin{array}{lll}\text { 16-Peace, Justice \& } \\
\text { Strong Institutions }\end{array}$ & $\mathbf{1 6 . 9}$ & $\begin{array}{l}\text { Provision of legal identity for all, including } \\
\text { birth registration }\end{array}$ \\
\hline
\end{tabular}

SOURCE: UNGA, 2015-2030 AGENDA FOR SUSTAINABLE DEVELOPMENT

While issues linked to the right to health, right to education, non-discrimination, right to identity as well as the right to protection from all forms of violence and exploitation such as the worst forms of child labour were immediately linked to children, other parts of the sustainable development agenda that tackle civil, economic, social and environmental protections are equally relevant for children's rights.

The explicit link between children, their rights and how development is financed was made in Resolution 34/16 of the UN Human Rights Council, which called for a child rights-based approach to implementing the 2030 Agenda, including 'to promote, protect, respect and fulfil the rights of the child and to mainstream them into all legislation, policies, programmes and budgets, as appropriate, aimed at implementing the 2030 Agenda' (UN HRC, 2017: para. 4). The resolution referenced the Addis Ababa Action Agenda (Third International Conference on Financing for Development, 2015) calling for the mobilisation and allocation of domestic and international resources in order to realise children's rights (UN HRC 2017: para. 8). International organisations, including 'funds, programmes, financing mechanisms, financial institutions' were called on to lend international support to governments in building capacity and implementing the 2030 Agenda in the context of the realisation of children's rights (UN HRC, 2017: para. 10).

\subsection{Outline and Methodology}

The position of multilateral development banks (MDBs) to the provision or facilitation of development financing remains central to the promotion of sustainable development. Children are enumerated among the key stakeholders and important potential beneficiaries when goals linked to achieving sustainable development are implemented. Children are clearly impacted when such goals are not achieved as well as when programmes and projects undertaken in the name of development result in undesirable outcomes. Yet, there is very little academic attention and corresponding scholarship on children's rights in development financing. Most inquiries into children's rights impacts of development financing activity, particularly through investment projects, are undertaken by 
a small number of non-governmental organisations. ${ }^{2}$ This article seeks to overcome the lack of scholarly reflection on the topic by mapping the landscape of interactions between children, their human rights and multilateral development banks (MDBs). First, the article broadly traces the impacts that project and programme financing by MDBs may have on children. Second, the article addresses the issue of MDBs as children's rights duty bearers. Third, the article delves into the world of global administrative regulation of MDBs from a children's rights perspective, analysing general competences of MDBs, programming and safeguard policies. Fourth, the article identifies gaps in children's rights protection that arise from the conditions and norms under which MDBs operate. Finally, the article sets out an agenda for future research and policy.

Findings in the article related to the state of the art on MDBs and children's rights are based on desk-research consisting of a review of academic and grey literature on the topic, as well as extensive analysis of regulations and policy documents originating from the various institutions analysed. To inform the findings of the study, policies of most notable MDBs at the global and regional level have been evaluated. The analysis devotes particular attention to the International Bank of Reconstruction and Development (IBRD) and the International Development Association (IDA), collectively called the "World Bank" as well as the private lending arm of the World Bank Group, the International Finance Corporation (IFC). At the regional MDв level, the analysis includes players from Asia, Africa, the Americas as well as Europe. The newest MDBs, namely the New Development Bank (NDB) of Brazil, Russia, India, China and South Africa (the so-called BRICs countries) and China-led Asian Infrastructure Investment Bank (АIIB) are also brought into the analysis.

\section{Mapping the Landscape of MDB s as Children's Rights Duty-Bearers: Legal Perspectives}

MDBS provide public financing, particularly in two distinct ways: providing policy financing to governments and project financing, which involves the

2 An NGO that has consistently been paying particular attention to children's rights in the work of multilateral development banks, with a focus on the World Bank, is the US-based Bank Information Center (BIC), which has also produced reports on projects supported by MDBs based on field research. In addition, the International Commission of Jurists (ICJ) published one of the few systematic reviews of MDв policies and accountability mechanism in relation to children in 2014: ICJ, Financial Institutions and the Rights of the Child: An Overview of Policies and Accountability Mechanisms, 2014 (https://www.icj.org/ new-icj-report-financial-institutions-and-the-rights-of-the-child/). 
private sector. The financing activities of MDBs may impact the provision of public goods and services when policy financing is provided directly to governments, often with conditionalities attached. The CRC Committee has underscored in its General Comment (GC) No. 19 on public budgeting that states should protect children's rights from encroachment by "third parties", which may include business enterprises or financial institutions such as MDв s when they affect the process of public budgeting (CRC Committee, 2016: para. 27(b)). As Abouharb and Cingranelli pointed out more than a decade ago, "[o]ther things being equal, governments of developing countries which implement structural adjustment conditions provide less protection of the economic and social human rights of their citizens' (Abouharb and Cingranelli, 2007: 32). With respect to M DB policy financing, the UN Independent Expert on foreign debt and human rights noted in his July 2019 report that the application of retrogressive economic reforms relying on austerity may result in violations of economic, social and cultural rights and that international financial institutions supporting these retrogressive measures may be liable for complicity in the resulting human rights violations (UNGA, 2019).

Besides macroeconomic policies, children and their rights are often directly and adversely impacted through programmes or projects financed by MDBs in sectors such as education or healthcare, particularly with respect to access and equality. Children's rights are furthermore concerned indirectly when projects necessitate interventions such as involuntary resettlement of communities. Children might also come into contact with the adverse impacts of projects financed to promote economic development when such projects cause the influx of workers into their communities or result in environmental pollution.

The last two decades have seen a clear civil society engagement in scrutinising the role of the World Bank (WB) and other MDBs in financing development projects. Of course, projects and programmes financed by MDBs can produce positive outcomes for children by seeking to change practices detrimental to children's wellbeing and rights. One example is the PROMINEs technical assistance project in the mining sector in the Democratic Republic of Congo (DRC), which was a 9o million USD project, co-financed by the wB and UK's Department for International Development (wB, 2019b). The project aimed to assist the DRC government in re-designing and renovating its regulatory and legislative mining framework, including through 'enhancing transparency and accountability, including traceability systems for so-called conflict minerals in Eastern Congo in cooperation with other institutions and actors' (WB, 2010: viii). The WB's project results report indicated that the objectives linked to the improvement of the working and living conditions of artisanal miners had been achieved, including 
by 'strengthen[ing] the position of women and children' and by removing 1,200 children present at mines and directing them to schooling in a pilot programme in cooperation with civil society actors, (WB, 2019a: 25).

Unfortunately, good practice examples are offset and upstaged by various iterations of how children are adversely impacted by projects financed or spearheaded by MDBs. As Wachenfeld notes:

Done well, such projects can bring important benefits for children: appropriate jobs and apprenticeships for those of working age, greater access to services, and new topics for learning and discussion at school. However, as is often is the case, children may be "invisible" in such complex undertakings unless a particular effort is made to "see" them and their interests from the very start of the process. Invisibility can result in serious effects on children's well-being.

(WACHENFELD, 2012)

Examples of children remaining invisible abound. The wв and the ADв were criticised for their financial support to Uzbekistan's agricultural sector and the IFC for the financing it provided to textile joint ventures during a period where the use of forced child labour in cotton fields was documented to be widespread. Civil society noted with concern that children, their rights and interests had not been appropriately accounted for in the preparatory stages of these projects (BIC and Ezgulik, 2013; HRW, 2013; IFC, 2015). Likewise, the Bujagali Hydropower Project, which was supported financially by the WB, the IFC, the AfDB as well as various national development finance institutions, came under scrutiny for the impacts of involuntary resettlement on the affected peoples, including children who experienced a decade-long struggle to access education and healthcare facilities as well as impacts on their nutritional intake as a result (Nampungu and Kasabiiti, 2012; BIC, 2013). Of course, children's rights impacts from MDB-financed projects can range wider and include increased susceptibility to communicable diseases due to the influx of workers to a project area and poor sanitation, a deterioration of living conditions, strained capacity at local schools and health clinics leading to poor educational or health outcomes. Further risks may include the sexual abuse and exploitation of children, child trafficking as well as children being recruited into harmful labour (Wachenfeld, 2012).

MDв financial support is considered an enabler and catalyser in attracting further public and private financing for development projects. The IFC conducted a survey with its private clients, which revealed that in addition to enhanced know-how, private clients considered that MDBs had a strong 
'ability to mobilize capital from additional sources' for projects and could provide a 'stamp of approval' (IFC, 2011: 29). According to one account, 'one dollar of capital supplied to an [international financial institution] by governments can lead to $\$ 12$ of private sector project investment', to be further augmented by repayments made to the lending financial institutions and taxes paid to the host State (IFC, 2011: 30). There is a clear need to scrutinise what the results of the catalyser and enabler role that $\mathrm{MDB}$ s play are, especially in contexts where they interact with individuals or groups such as children, who may be invisible or have specific vulnerabilities.

\subsection{Diversity of Duty-Bearers under the cRc}

One uncontested tenet of human rights law, and in extension, children's rights law, is that States are duty-bearers. Traditionally, States have been considered the primary and sometimes, the only human rights duty-bearers. The CRC, however, is expressly less State-centric in the way it approaches duty-bearers. While the Convention is addressed to States Parties and sets out their obligations in the context of substantive rights, those with duties towards children effectively extend beyond the State. The CRC explicitly refers to 'the responsibilities, rights and duties of parents or, where applicable, the members of the extended family or community as provided for by local custom, legal guardians or other persons legally responsible for the child' (Art. 5). In doing so, the CRC establishes a multidimensional approach to duties towards the child. The parent-child relationship is one dimension, the child-State relationship is another dimension. In addition, there are duties that govern the relationship of the child to the extended family, community as well as those acting as proxies for parents such as legal guardians (Art. 5). Other dimensions recognised by the CRC extend to 'public or private social welfare institutions, courts of law, administrative authorities or legislative bodies' that may come into contact with the child (Art. 3) and the mass media (Art. 17) (Vandenhole et al., 2019).

Furthermore, States Parties have an obligation to take all appropriate measures for the implementation of the rights contained in the CRC and for economic, social and cultural rights, to do so 'to the maximum extent of their available resources, and where needed, within the framework of international cooperation' (Art. 4). The reference to international cooperation points to States' roles both in bilateral as well as multilateral mechanisms, such as those through multilateral agencies as alluded to in Article 45.

\subsection{Multilateral Development Banks as Children's Rights Duty-Bearers}

The CRC Committee noted in its General Comment (GC) No. 16 that States have a dual duty when engaging with international development, finance 
and trade institutions in the context of business activities. Their first duty is linked to complying with their own children's rights obligations as members of these organisations and not 'accept[ing] loans ... or agree[ing] to conditions ... if these loans or policies are likely to result in violations of the rights of children' (CRC Committee, 2013: para 47). A similar assessment had been made by the Committee on Economic, Social and Cultural Rights (CESCR) in its GC No. 14 on the highest attainable standard of health and its GC No. 15 on the right to water (CESCR, 2000; CESCR, 2002). In fact, the CESCR had called on states parties to 'pay greater attention to the protection of the right to health [as well as the right to water] in influencing the lending policies, credit agreements and international measures' (CESCR, 2000: para. 39; CESCR, 2002: para. 36). According to the CRC Committee, states are also under a second obligation to:

take all reasonable actions and measures to ensure that such organizations act in accordance with the [CRCs and the ops] thereto in their decision-making and operations, as well as when entering into agreements or establishing guidelines relevant to the business sector.

(CRC COMMITTEE, 2013: PARA. 48)

States should also consider the full spectrum of children's rights beyond the eradication of child labour when engaging with international development, finance and trade organisations in this regard (CRC Committee, 2013).

International organisations, including $\mathrm{MDB}$, have also been directly addressed as human rights duty-bearers by UN treaty bodies in various GCS. The CESCR has referenced the role of international organisations in the UN system in cooperating with states parties in the context of the realisation of the right to health and specifically called on international financial institutions that they 'should pay greater attention to the protection of the right to health [and the right to water] in their lending policies, credit agreements and structural adjustment programmes [and other projects]' (CESCR, 2000: para. 64; CESCR, 2002: para. 6o).

The CRC Committee went even further to address the children's rights duties of international organisations when engaging with businesses:

International organizations should have standards and procedures to assess the risk of harm to children in conjunction with new projects and to take measures to mitigate risks of such harm. These organizations should put in place procedures and mechanisms to identify, address and remedy violations of children's rights in accordance with existing 
international standards, including when they are committed by or result from activities of businesses linked to or funded by them.

(CRC COMMITTEE, 2013: PARA. 48)

Thus, according to the CRC Committee, children's rights-focused impact and risk assessments as well as procedures for effective accountability through the identification and remediation of violations in the context of development projects is not only incumbent upon States parties but also upon financial institutions, such as MDBs.

Administrative Regulation of MD в s from a Children's Rights Perspective

The need for standards and procedures internal to MDBs that should be utilised in 'identify[ing], address[ing] and remedy[ing]' risks to and violations of children's rights, as recognised by the CRC Committee (CRC Committee, 2013: para. 48), is central to a child rights-friendly or at least child rights-cognisant functioning of $\mathrm{MDB}$. Whether the MDBs' functional and regulatory frameworks respond to these requirements necessitates a systematic review that is grounded in the real lived experiences of children. Departing from this premise, the following section attempts to address a gap in human rights and children's rights literature by inspecting the administrative regulation of MD B $\mathrm{S}$ from a children's rights perspective. The section looks into MDв mandates, programming and safeguard policies and tries to evaluate whether and to what extent the regulations on paper correspond to the needs of children with a view to the realisation of their rights.

\section{1}

\section{MDв Mandates, Programmes and Children's Rights}

MDBs are, legally speaking, international organisations set up through intergovernmental agreements between states parties. These states parties agree to contribute financially to and become shareholders in a bank that seeks usually to foster economic growth and economic cooperation globally or in a defined region and offer development financing to programmes, projects and policies in member countries (IDB, 1996; ADB, 1994; IBRD, 2012; NDB, 2015; AIIB, 2015 AfDB, 2016). The agreements establishing major MDBs do not refer to the realisation of human rights, much less children's rights, as a part of these institutions' mandate. Indirect engagement with the realisation of human rights may be inferred from the focus on development and its possible spill over effects but is mostly not made explicit. The agreement establishing the IDB and the AfDB are in fact 
rather unique in listing the purpose of the organisation as 'contribut[ing] to the acceleration of the process of economic and social development in the region' (IDB, 1996: Article 1, Section 1). Agreements establishing other major MDBs have simply chosen to refer to the importance of social development (alongside economic development, of course) in their preambles (IDA, 1960; NDB, 2015; AIIB, 2015) or to leave it out altogether (ADB, 1994; IFC, 2012b).

The WBG is the world's pioneering development bank and perhaps the only one that has true global outreach in terms of its activities in policy and project-based finance. For a long time, WBG's explicit engagement with human rights was considered a taboo subject, based on the political prohibition under Article IV.10 of the IBRD Articles of Agreement. All regional MDв have replicated the WBG's now famous 'political prohibition', which stipulates that:

The Bank and its officers shall not interfere in the political affairs of any member; nor shall they be influenced in their decisions by the political character of the member or members concerned. Only economic considerations shall be relevant to their decisions, and these considerations shall be weighed impartially in order to achieve the [Bank's] purposes $[\ldots]$

(IBRD, 2012: SECTION 10)

The political prohibition was taken at face value for decades and its expansive interpretation meant that the WBG could avoid engagement with human rights in its work despite human rights being increasingly recognised as an integral part of development in all its aspects (Alston, 2019).

Reflecting the shift in policy and discourse as one that recognised the organic links between human rights and development, wB's then Senior Vice President and General Counsel, Ibrahim I. Shihata, recognised that the Bank's prohibition of intervention in the political affairs of a recipient country did not preclude it from 'promot[ing] a broad array of economic, social and cultural human rights' through its increased 'lending for health, education, nutrition, reproductive health, and other aspects of human capital development' (Shihata, 1996: 388). According to Shihata, the ws had made the decision to broaden the scope of its activities to include the promotion of 'children's rights to development, health and education' through the projects it supports (Shihata, 1996: 405). Others working within the WB also began conceding that human rights were increasingly becoming relevant to its work (Palacio, 2006; Sarfaty, 2009). The need to move beyond the constraints in the way the so-called political prohibition has thus far been formally interpreted to allow for a more comprehensive engagement with human rights is apparent in light 
of the de facto work of the Bank in various domains, including education, health as well as conditions of living (Cissé, 2011).

An early UNICEF study argued, based on the existence of a financing prohibition for projects contravening a state's legal obligations under environmental law within WB's operational policies:

It would seem to follow logically that ... the same reasoning would apply in relation to human rights. And that logic would be even more compelling in relation to children's rights, because of the virtually universal nature of their acceptance. Not a single country to which the World Bank would ever make a loan or a grant is not a party to the CRC. There is, in principle, no reason why the environmental precedent could not be extended to the human rights field, in a manner which would in each case be readily compatible with the Bank's mandate.

(ALSTON AND TOBIN, 2005: 80)

From an operational perspective, the шв had already accepted an active role in the protection and promotion of children's rights starting with the 199os, without framing its involvement in rights language. In fact, that premise is true not only for the $\mathrm{WB}$ but for many regional MDBs that run programmes and projects in sectors linked to essential public services. With such expansive operational outreach into child development through health and education, policy work seeking to improve living conditions and increase the standard of living in developing countries, it is all the more important that the operations and decisions of the MDBs are covered by corresponding duties. In what follows, this article showcases the various common normative strands in the administrative governance of MDB s and how they relate to children's rights, both with respect to broader self-regulation and safeguard policies and to children's rights-specific norms.

\subsection{Broader Self-regulation and Safeguard Policies}

The safeguard policies and standards are designed by M в s to assess, identify and manage environmental and social risks of the projects they finance. Various major MD B s have reviewed or have been reviewing their safeguards, including the IFC that revised its Performance Standards in 2012, WB that adopted a new Environmental and Social Framework (ESF) which came into force in 2018 and the Inter-American Development Bank (IDB) that is currently undergoing the process. Safeguard policies and standards adopted by MDBs do not, by most measures, provide adequate human rights and children's rights protections. There are, however, a number of human rights and children's rights related 
issues that are regulated by such policies and standards when MDB s make project financing decisions.

In terms of their scope, most safeguard policies and standards entail a requirement of ex ante environmental and social impact assessments, an expectation of due diligence from countries and private actors being financed, specific protections for groups considered prone to vulnerability and marginalisation as well as an indication of how recourse for failure to comply with safeguards can be sought through internal mechanisms.

Despite the differences in the membership and geographical focus of various MDBs, their safeguard and accountability policies have fundamental commonalities. These often - but not always - include a lack of explicit and mandatory engagement with human rights broadly speaking, particular attention to so-called disadvantaged or vulnerable groups, special protections for indigenous populations as well as consultation and consent requirements.

\subsubsection{Lack of Mandatory and Explicit Engagement with Human Rights}

Most MDBs lack an explicit and mandatory engagement with human rights, including children's human rights, in their self-regulatory frameworks, even after the modernisation of said frameworks, with the exception of European MDBs. A 2015 comparison study of the safeguards of various MDB s commissioned by the шв during the review of its safeguards noted that:

None of the MDBs (other than EIB) [footnote omitted] ha[d] a cross-cutting policy requiring "human rights" compliance. Most of the other MDBs refer[ed] to "human rights" in supportive aspirational terms while recognizing the responsibility of clients to respect human rights.

(HIMBERG, 2015: ix)

In fact, the new $\mathrm{WB}$ safeguards demonstrate that a comprehensive MDB engagement with binding human rights norms remains difficult to achieve. Dann and Riegner consider that the new safeguards 'create ... mainly procedural rights for affected people to participate and be heard in the development of a project and its implementation' as well as some substantive guarantees of compensation, amounting to 'an incipient regime of "simple" individual rights beyond the framework of human rights law' (Dann and Riegner, 2019: 543). In addition, the шв has also somewhat distanced itself from the scope of application of the Environmental and Social Standards contained in the safeguards framework by noting that it applies to borrowers, while the WB Environmental and Social Policy for Investment Project Financing (IPF) is said to apply to the 
Bank itself when it finances investment projects (WB, 2018). Thus, the environmental and social protections and risk management applicable to the WB itself are circumscribed by this policy and the relevant Bank Directives. The policy does refer to due diligence requirements in assessing the environmental and social risks and impacts, which include issues such as human security, non-discrimination, involuntary resettlement and protection of workers' rights but not to human rights per se, meaning children's rights beyond labour issues also go unregulated (WB, 2018).

References to human rights in the new wB safeguards are limited to two instances, within what may be considered its non-binding preamble entitled, 'A Vision for Sustainable Development' and in Environmental and Social Standard 7 on Indigenous Peoples/Sub-Saharan African Historically Underserved Traditional Local Communities (wB, 2016a). The preamble defines WB's development agenda as one espousing 'social development and inclusion' and contains aspirational language on human rights in support of 'the realization of human rights expressed in the Universal Declaration of Human Rights' and progressive realisation of human rights by member states (wB, 2016a: Preamble).

Environmental and Social Standard 1 on Assessment and Management of Environmental and Social Risks and Impacts makes a reference to borrower obligations under national law as well as international treaties and agreements 'directly applicable to the project' (wB, 2016a: Ess 1, para. 26). Given that all human rights treaties to which a borrower is party would be applicable to all projects that foresee an impact on human populations, this provision may provide an entry point for bringing human rights requirements into the $\mathrm{WB}$ assessment processes. This is especially true in the case of the CRC, which has been almost universally ratified. This being said, what the direct applicability condition will amount to and whether it will be utilised to constrain the inclusion of human rights law into the safeguard requirements remain to be seen in practice.

The IFC contains commitments under its Performance Standards that reiterate the normative basis of the UN Framework and Guiding Principles on Business and Human Rights (UNGPs) that the businesses it finances have a responsibility to respect human rights. The IFC's role in the process is defined as a supervisory one, which involves 'undertak[ing] due diligence of the level and quality of the risks and impacts identification process carried out by its clients against the requirements of the [Performance Standard], informed by country, sector, and sponsor knowledge' (IFC, 2012a: para. 12). In practice, the supervision role may lead to a stronger engagement with children's rights but often only when external accountability pressure is exerted through political 
or social means. For instance, the WBG has decided to freeze direct investments into private for-profit schooling in March $202 \mathrm{O}$ and to call for an Independent Evaluation Group inquiry into the IFC's existing investments, 'including impacts on educational outcomes, access, poverty and inequality' in response to concerns raised by the US House Financial Services Committee as it was looking to approve US financing for WB capital increase (Malpass, 2020). This move came in response to long-standing and compounding criticism of IFC investments in private for-profit primary and secondary education, jeopardising children's right to education (Klees et al., 2012; ActionAid International et al., 2019; Malouf Bous and Far, 2019).

The widest ranging human rights engagements by MDBs are to be found in the European region. The European Investment Bank (ЕIв) and European Bank for Reconstruction and Development (EBRD) both contain direct human rights provisions in their safeguard policies. EІв has committed to not 'financ[ing] projects which result in a violation of human rights',(EIB, 2009: Preamble), while EBRD's Environmental and Social Policy (ESP) recognises the responsibility of its 'clients' and their business activities to 'respect ... human rights, avoid ... infringement on the human rights of others, and address ... adverse human rights impacts that their business activities may cause, or to which they may contribute' (EBRD, 2014: para. 9). The internationally recognised international human rights standards include those in the UDHR, the International Bill of Human Rights and the eight core conventions of the International Labour Organisation. (EBRD, 2O14) Although the CRC is left out of the scope of human rights duties of clients, the ILO Conventions 138 and 182 on minimum age and the worst forms of child labour, respectively, fall within the definition.

The EIB's Environmental and Social Principles and Standards (ESPS) are said to be 'derived from EU policy and law', including in addition to the Charter of Fundamental Rights, the environmental principles underlying the Treaty on EU, environmental and social policies contained in EU legislation in areas of Bank competence and work alongside other development commitments (EIB, 2009: 8, para. 15). The commitment to social and environmental issues is seen as an intertwined task of combining the economic objectives of sustainable development with its other two dimensions: the wellbeing of the environment and of individuals and groups. The Е гв claims to use a rights-based approach in assessing the social dimensions of a project, based on the EU Charter of Fundamental Rights and the UDHR. EIB is bound by the EU Charter of Fundamental Rights in its decisions and operations, which reaffirms the rights contained, inter alia, in 'international obligations common to the Member States, ... the [ECHR], the Social Charters adopted by the Community and by 
the [CoE]' as well as ECJ and ECtHR case law (EU, 200o: Preamble). Linked to EIB's work, the Charter states that ' $[a]$ high level of human health protection shall be ensured in the definition and implementation of all Union policies and activities' and that all policies of the EU must integrate '[a] high level of environmental protection and the improvement of the quality of the environment' (EU, 2000: Articles 35 and 37, respectively). The related 'responsibilities and duties' are owed not only to EU citizens but also 'to other persons, to the human community and to future generations' (EU, 2000: Preamble). Although EU law does not legally apply outside of the EU's borders, the Егв considers the standards set by EU law as its benchmark. EIB's standards dictate that the bank will not finance projects that fail to meet the environmental and social requirements and comply with relevant EU legislation. Additionally, if EU standards in a given area are not sufficiently developed or comprehensive, the ЕІв may turn to other sources of 'good international practice' (EIB, 2009: 9, para. 22). Thus, beyond the EU and Enlargement Countries, EIB's human rights-based approach means 'mainstreaming the principles of human rights law' when undertaking assessments of proposed projects. (EIB, 2009: 18, paras. 48-49).

The EIB is a rather special case on account of its status as an institution of the EU, formally governed and bound by EU's human rights commitments as set out in the Charter of Fundamental Rights as well as other internal regulations. EBRD, on the other hand, is on a par with its African, Asian and Inter-American counterparts, in terms of its reliance on self-regulation that does not contain explicit human rights provisions but often, aspirational references to the realisation of human rights or the relevance thereof. Likewise, the African Development Bank's (AfDB) Integrated Safeguards System uses its Preamble to underscore the indivisible nature of human rights to include economic and social rights and affirms its respect for human rights pronounced in the UN Charter and the African Charter on Human and Peoples' Rights. In addition, member States are 'encourage[d] ... to observe international human rights norms, standards, and best practices' based on the international and regional human rights conventions they have ratified (AfDB, 2013b: Preamble), which include the CRC as well as the African Charter on the Rights and Welfare of the Child. As outliers, newer мDвs New Development Bank (NDB) and Asian Infrastructure Investment Bank do not engage with human rights even in aspirational terms in their broader mandate. This being said, the NDB does reference human rights with respect to the implementation of its safeguards when the human rights of indigenous peoples, among other things, may be affected by a project. (NDB, 2016)

The absence of clear human rights duties in the administrative legal governance of MDBs constitutes a particular lockout of human rights when MDB 
performance is assessed ex post facto, for instance, in relation to grievances by affected communities. Because MDBs cannot be routinely subjected to domestic judicial review due to the widespread immunities they currently enjoy, their impacts on rights-holders can often only be measured against their self-regulatory norms through internal review mechanisms (Erdem Türkelli, 2O2Ob). If MDB self-regulatory norms do not contain human rights commitments and duties, one very important consequence is that internal review mechanisms cannot effectively address human rights claims and provide remedies.

\subsubsection{Special protections for Indigenous Peoples}

Most MDB safeguard policies reflect that binding human rights duties for borrowers in the specific context of indigenous people's rights. For instance, the first objective of wB's Environmental and Social Standard 7 is listed as 'ensur[ing] that the development process fosters full respect for the human rights, dignity, aspirations, identity, culture, and natural resource-based livelihoods of Indigenous Peoples/Sub-Saharan African Historically Underserved Traditional Local Communities' (WB, 2016a: ESS 7). Similar language may be found in the safeguards of the ADB, the IDB as well as the ЕІВ. АDB has additional provisions for designing and implementing projects to deliver 'culturally appropriate social and economic benefits' to indigenous peoples (ADB, 2009: Appendix 3, para. 3). EIB requires the drafting of an Indigenous Peoples Development Plan (IPDP), either as a standalone document or as a part of the broader social management plan, with a focus specifically on Free, Prior and Informed Consent (FPIC) of the affected indigenous peoples, which is also in line with the WB's Environmental and Social Standard 7. One important requirement in the EIB safeguards is that ' $[t]$ he promoter is expected to publicly disclose the final draft of the IPDP to the affected indigenous peoples' communities in an appropriate form, manner, and language' (EIB, 2009: ESH, ESS 7, para. 27). Unfortunately, the recognition of delivering project guidelines as affects communities or individuals in a form, manner and language that is appropriate for its audience is not translated into how MDBs ought to communicate with children in affected communities, whether they are indigenous or not. None of the standards included in MDB self-regulatory frameworks on indigenous peoples' go beyond recognising that 'women and children, who have frequently been marginalised both within their own communities and as a result of external developments, may have specific needs' (WB, 2016a: ESS 7, para. 3). Even then, the special attention that ought to be paid seldom materialises because there are no specific requirements for MDB staff to do so. For example, when the шв and the егв financed the Olkaria Geothermal Power Project in Kenya, which involuntarily displaced Maasai communities in 
the area, it was reported that the consultation and decision-making processes had not adequately involved all relevant members of the community (Koissaba, 2018). In addition, similarly to the Bujagali case, the Olkaria project's impacts in relation to children dropping out of school due to impoverished households resulting from resettlement and inability to pay school fees had not been identified and mitigated prior to the resettlement (EIB Complaints Mechanism, 2015). This meant that the grievances of youth and women in relation to the restoration of their livelihoods had to be subject to mediation at the EIB Complaints Mechanisms (Koissaba, 2018). Because the internal rules of MDBs do not as such address how they should interact with indigenous peoples, including indigenous children who may be experiencing intersectional exclusions, how the specific needs of these individuals and communities ought to be addressed is often left to the discretion of the MDB, the borrower countries and the clients.

\subsubsection{Attention to so-called 'Disadvantaged or Vulnerable' Groups}

The attention to so-called 'disadvantaged or vulnerable' groups permeates the standards purporting to self-regulate MDв activities and policies across the board. The wв Environmental and Social Policy for Investment Project Financing (IPF) references the new WB Directive Addressing Risks and Impacts on Disadvantaged or Vulnerable Individuals or Groups to be employed when projects present particular risks and impacts on 'individuals or groups, who because of their particular circumstances, may be disadvantaged or vulnerable' (wB, 2016(b): Section v, para. 3). This Directive gives wB staff an explicit mandate to conduct due diligence on the borrower's environmental and social safeguards. Children are covered as belonging to disadvantaged or vulnerable groups, given that the Directive allows for age to be a consideration when assigning such status and points to the special situation of minors alongside the elderly, especially when they are separated from families or other communal support structures (WB, 2016(b): Section II, para. 1). Accordingly, wB task teams have to ascertain through due diligence with a view to informing the final decision making on a project proposal, whether:

the environmental and social assessment has properly identified the disadvantaged or vulnerable individuals or groups; and appropriate differentiated mitigation measures have been incorporated into project design and documented in relevant project documents so that adverse impacts do not fall disproportionately on the disadvantaged or vulnerable, and they are not disadvantaged in sharing any development benefits resulting from the project.

(WB, 2016(B): SECTION III, PARA. 6) 
In addition, the task team is required to ensure that the participation of disadvantaged or vulnerable persons/groups in consultations is guaranteed. When the WB team identifies possible harm to disadvantaged or vulnerable individuals or groups, it is another unit, the Operations Environmental and Social Review Committee, that decides whether and how the project will proceed and with what involvement from the team. (WB, 2019). Although implementation will remain an important challenge, project-affected vulnerable or disadvantaged individuals or groups, including children, will now have a basis on which to seek redress for the decisions undertaken by the wB itself when they fall short of what is required by the Directive. Neither the Directive nor the new WB ESF recognise rights as the foundation of their obligation towards individuals or groups.

At the regional level, an accent on individuals or groups that may be more vulnerable or marginalised and therefore require enhanced protection is to be found in the policies of many MDBS. ADB's Safeguard Policy Statement, for instance, notes that environmental assessments conducted as a part of ADB's project finance efforts will inspect whether 'particular individuals and groups [such as, inter alia, children] may be differentially or disproportionately affected ... because of their disadvantaged or vulnerable status' (ADB, 2009: 31). If identified, such individuals or groups will benefit from 'targeted and differentiated measures' to offset the disproportionate burdens from environmental impacts. EIB's safeguard require it to 'pay ... particular attention to the rights of disadvantaged groups, and the impacts that a project might have on people in both the workplace and the local community' (EIB 2009: 6, para. 8). The NDB's Environment and Social Framework takes a broader view by calling for the 'inclusive sharing of development benefits and opportunities including among the traditionally deprived sections such as the poor, disadvantaged, women, children and minorities' (NDB, 2016: Overview, para. C.5.a).

Often, even when risk and impact assessments are undertaken and consultations are conducted, the protection accorded to individuals or groups prone to marginalisation fall below the threshold required by human rights standards.

\subsubsection{Consultation and Consent Requirements}

Many MDBs include consultation and consent requirements linked to project lending. The consultation and consent requirements vary widely depending on the мDв. In most cases, FPIC is reserved for indigenous peoples (АDB, 2009; WB, 2016a) and sometimes specifically with respect to involuntary resettlement (EIB, 2009; EBRD, 2014). Often, project environmental and social assessments require consultation. For instance, AfDB safeguard policies require project borrowers or clients to ascertain that affected communities 
participate in the environmental and social assessment process 'in a free, prior and informed manner' but falls short of requiring the consent (AfDB, 2013b: 16). Likewise, the NDB's requirements centre around a 'meaningful consultation process' in line with national legislation of borrowing countries (NDB, 2016: 10, para. 22). The importance of gender inclusivity, attention to vulnerable groups as well as the participation of affected peoples in the consultation process is underscored. ADB's safeguards require 'particular attention to the needs of vulnerable groups' including women and children in carrying out meaningful consultations in cases of involuntary resettlement (ADB, 2009: 16).

\subsection{Children and Children's Rights in Safeguards}

From a children's rights-specific perspective, safeguard and accountability policies of most MDBs generally have a very narrow focus, which provides explicit protections against economic exploitation in the form of harmful and hazardous child labour. Children's rights are not referenced by MDBs in their work as such but children are often explicitly included in the definition of disadvantaged or vulnerable groups and among groups to be consulted.

\subsubsection{Protection from Economic Exploitation}

A survey of self-regulation within different regional and global financial institutions in fact demonstrates that with respect specifically to the spectrum of children's rights, the most readily accepted principles by regional and global financial institutions centres on the prohibition of harmful child labour. The WB's new safeguards framework under Environmental and Social Standard 2 aims to prevent the use of forced and child labour in projects funded by the $\mathrm{WB}$ ( $\mathrm{WB}, 2016 \mathrm{a})$. This is a new addition to wB safeguards as previous policies and standards did not include specific labour protections.

In addition to demanding respect for human rights as a due diligence requirement, IFC's Performance Standards on Environmental and Social Sustainability also prohibit the employment of children in exploitative, hazardous or harmful labour by IFC clients (IFC, 2012a). In addition, the due diligence requirement for child labour is extended to the primary supply chain of IF C's clients:

Where there is a high risk of child labour or forced labour [footnote omitted] in the primary supply chain, the client will identify those risks ... If child labour or forced labour cases are identified, the client will take appropriate steps to remedy them. The client will monitor its primary supply chain on an ongoing basis in order to identify any significant changes 
in its supply chain and if new risks or incidents of child and/or forced labour are identified, the client will take appropriate steps to remedy them. (IFC, 2012a: PS 2, PARA. 27)

Although the CRC is not considered by the IFC to be included in the definition of human rights that businesses have a "responsibility" to respect (which is limited to the UDHR and the International Bill of Rights), ILO Conventions 138 and 182 on Minimum Age and Worst Forms of Child Labour are comprised by the definition.

Performance Standards apply to the direct project finance that IFC provides but not to projects financed through financial intermediaries. IFC also applies the IFC Exclusion list, which applies to financial intermediaries as well. In addition, all financial intermediaries have to apply additional exclusions including 'production or activities involving harmful or exploitative forms of forced labour/harmful child labour' (IFC, 2007). The IFC Exclusion List and the exclusion of products or activities involving harmful child labour (and harmful or exploitative forms of forced labour) are replicated in the safeguard policies of many regional or national financial institutions (IDB, 2006c; ADB, 2009; AfDB, 2013a; EDFI, 2011; AIIB, 2016).

As regards children and their rights, regional MDB s also incorporate protections against economic exploitation of children. In the European region, EBRD's Performance Requirement 2 on Labour and Working Conditions requires EBRD clients to abide by the highest degree of child protection prospects offered by national laws and international labour standards (EBRD, 2014: para. 9). Accordingly, clients are -

not [to] employ children in a manner that is economically exploitative, or is likely to be hazardous or to interfere with the child's education, or to be harmful to the child's health or physical, mental, spiritual, moral, or social development.

(EBRD, 2014: PARA. 10)

Even when the work is deemed non-hazardous, risk assessment and the monitoring of working hours and conditions, and health are required for young workers under 18 years of age (EBRD, 2014).

EIB's Standard 8 on Labour Standards entails respect for ILO Core Labour standards, which include prohibition of child labour as per ILO Conventions 138 and 182 and notes that projects that 'employ, use or benefit from harmful child labour' will not be financed by the ЕІв (ЕІв, 2009: 72, para. 17). The EIB's protection of labour standards is more uniform than its protection of human rights, 
given that the labour standards apply to all operations that the EIB finances are 'throughout their entire lifecycle' without distinction of location within or outside the EU (EIB, 2009). Article 32 of the EU Charter of Fundamental Rights, by which the EIB is bound, prohibits child labour and designates the minimum school leaving-age as the minimum threshold age for admission into employment. In addition, the article extends young people protection against economic exploitation and harmful and hazardous forms of labour (EU, 2009). Borrowers benefiting from ЕІB funding are required to report to the ЕІB about any persons under the age of 18 employed in the project, specifying the nature of their work and to abide by minimum age conditions, pointing to the importance of the rights at work when youth workers are employed (EIB, 2009).

The African region has similar protections for children. The objectives of AfDB's Operational Safeguard 5 on Labour conditions, health and safety include '[a]lign[ing] Bank requirements with the ILO Core Labour Standards, and the CRC, where national laws do not provide equivalent protection' and to '[p]rotect the workforce from inequality, social exclusion, child labour, and forced labour' (AfDB, 2013b: 49). The employment of children in work that is exploitative, likely to be hazardous, harmful or interfere with education, is prohibited. In the Asian region, the АDВ prohibits the funding of the 'production or activities involving harmful or exploitative forms of forced labor or child labor' (ADB, 2009: 76).

In the Inter-American region, the IDB lists non-compliance with Fundamental Principles and Rights at Work including the 'prohibition of child labor' as well as employment of those under 18 in 'hazardous conditions ... [or] at night' as a basis for excluding a possible operation from IDв Finance (IDB, 2006c). While there is no specific mention of children in the ID в Policy on Involuntary Resettlement, the Principles and Guidelines on Involuntary Resettlement note that the ID в must take into account '[ $t$ ] he educational needs of the population' and time possible relocations so that they do not coincide with the school year, given that displacement creates real risks of interruption of schooling or drop-outs for children (IDB, 1999: 9).

In the Asian region, the ADB refers to core labour standards without explicitly singling out the prohibited use of child labour in projects but lists activities using harmful and exploitative forms of child labour as a disqualifier from ADB financing (ADB, 2009). The China-led AIIB's Environmental and Social Framework does require its clients to ensure that children (persons under the age of 18) are not employed in its projects as a general rule. On the other hand, the Framework notes the facility provided by Article 3.3 of the ILO Convention 138 in allowing member states to enact legislation that can allow children over the age of 16 to work in conditions where their health, safety and morals are fully protected (AIIB, 2016). 
The review of most MDB safeguard policies and norms demonstrate a consensus on the need to protect children from economic exploitation, particularly in the form of hazardous or harmful child labour. Interestingly, the policies of the BRICs-led NDB does not offer such clear-cut protections against children's economic exploitation in the case of project lending more specifically beyond the client responsibility to meet domestic labour protection requirements and ILO Conventions applicable to the host country and do not include goods or services produced by child labour in their exclusion lists (NDB, 2016).

Given the widely institutionalised and regulated nature of hazardous and harmful child labour prohibitions in the self-regulatory frameworks of MDв s, the funded investment projects are often found to be compliant with the prohibition. One exception with respect to child labour has been the financial support provided by the WB and ADB to irrigation projects in Uzbekistan, where allegations of the use of state-orchestrated forced child labour propelled civil society organisations to launch complaints with the wB Inspection Panel and the IFC's Compliance Advisor/Ombudsman. Because the issue had been regulated, the conclusions of the monitoring bodies led to findings of insufficient ex ante due diligence and resulted in additional safeguards being introduced for the institutional engagements in Uzbekistan, albeit after a lengthy civil society campaign to that end (Erdem Türkelli, 2020a).

\subsubsection{Children as a 'Vulnerable' Group}

What can be broadly observed from the various standards in the administrative regulation of MDB $\mathrm{s}$ is that children are often subsumed into the broader category of 'disadvantaged or vulnerable' groups. In the preamble of the WB ESF, children are enumerated among others such as women, persons with disabilities, minorities and youth, 'who are often excluded from development process' and commits to removing barriers and ascertaining a public voice for these groups (WB, 2016a). Other MDBs also concur (ADB, 2009; EIB, 2009; AfDB, 2013b; EBRD, 2014; NDB, 2016). Inter-American Development Bank's (IDB) Environment and Safeguards Compliance Policy, in contrast to its global, African, Asian and European counterparts, does not offer specific references to the special situation of children as a part of marginalised or disadvantaged groups or persons (IDB, 2006a).

The definition of a vulnerable group is often based on the more limited ability to cope with and lower resilience to social risks (EIB, 2009). EIB's safeguards consider the rights of the child among the 'principal human rights' within the context of its Standard 7 on safeguards for vulnerable groups, complemented by the recognition within this context of non-discrimination and equal treatment as fundamental human rights principles, which is the sole reference to 
'children's rights' in the framework (EIB, 2009). One population among vulnerable groups that may be particularly important in MDв projects is child-headed households (EBRD, 2014), although there is no clarity as to how engagement with children heading households ought to happen.

IDB's Environment and Safeguards Compliance Policy, in contrast to its African, Asian and European counterparts, does not offer specific references to the special situation of children as a part of marginalised or disadvantaged groups or persons. Nonetheless, the IBD's Operational Policy on Indigenous Peoples recognises the issue of intersectionality which leads to the further disadvantaged situation of indigenous children, who are more at risk of malnutrition, school dropout, problems in access to education and healthcare. Consequently, it requires that ID B staff 'support for the participation and leadership by, and protection of women, the elderly, youth and children, and for the promotion of equal rights' (IDB, 2006b: 7). However, there is no operational clarity into how and through what means that should be achieved. AfDB's Integrated Safeguard Policy Statement also recognises the issues around intersectionality, given that 'some categories of children' such as orphaned children or those who are homeless may figure among the most vulnerable populations with which the AfDB will engage (AfDB, 2013b: 16). Intersectionality presents further challenges for children in having their rights realised. The wB-funded Education Quality For Equality Project for Lesotho which aimed to increase the quality of education in low performing schools to boost the country's economic growth, which was reportedly not designed in a manner ensuring inclusivity in access for all, has resulted in high drop out and absenteeism among children and youth with disabilities (Lesotho National Federation of Organisations of the Disabled, 2018).

Logically, with heightened vulnerability of project affected populations, such as children, ought to come more responsibility on the part of the MDBs to assess, prevent, mitigate and redress impacts. While this assumption is made implicitly, it has not been recognised explicitly in a way that provides watertight protections to rights-holders. For example, there is a well-known risk of sexual abuse and exploitation, particularly impacting girl children due to influx of workers into host communities during infrastructure projects, but this risk can often remain invisible. The WB was confronted with allegations of the sexual exploitation of girl children by road workers employed in the Uganda Transport Sector Development Project (Joy for Children, Uganda and BIC, 2015), which prompted it to cancel the project and withdraw financial support upon the substantiation of the allegations after a wB Inspection Panel investigation (wB Inspection Panel, 2016). Impact assessments undertaken prior to the approval of the project had identified children's rights risks 
related to resettlement and disruption of schooling, but risks around child sexual abuse and exploitation, which later materialised, were completely missed (Erdem Türkelli, 2020a), given the absence of a children's rights impact assessment requirement that comprehensively assessed all aspects of children's rights. Similarly, the possibility of the exposure of girls and women to sexual violence and exploitation emerged out of a compliance report from the ADB's Compliance Review Panel (CRP) on the Nenskra Hydropower Project in Georgia (ADB, 2018). This risk had not been considered during the ex ante social impact assessment of the project. In fact, the social impact assessment had not assessed impacts on children at all, even though impacts on other groups prone to marginalisation such as women and persons with disabilities had been inspected (ADB, 2017).

\subsubsection{Children's Right to Participate}

Children's right to participate in project design and implementation with respect to environmental and social impacts is often not portrayed as a standalone right. Again, children are considered among a broader group of affected persons within communities that host investments. The participation rights of affected persons are specifically recognised with regards to consultation processes, hence, giving them a right to be consulted. In addition, affected persons are often accorded the right to remedy and redress for adverse impacts of M В -financed projects. The right to be consulted and the right to seek redress are complementary in that deficiencies in the realisation of the right to be consulted frequently lead to the necessity of redress for foreseeable harms that are not prevented.

"Meaningful consultation" needs to be "tailored to the needs of disadvantaged and vulnerable groups' (ADB, 2009: 10, para. 32 ) and sometimes children are explicitly mentioned in this context (for instance, NBD, 2016: ESS 2.C.3). The children among affected persons are not seen as active agents but rather passive recipients of the tailored attention. This is striking when juxtaposed with the CRC which creates an obligation to ensure that a child is capable of forming his or her own views the right to express those views freely in all matters affecting the child' and a corresponding obligation to give due weight to the views of the child in accordance with their age and maturity (UN, 1989: Article 12.1).

Although many MDBs require their management as well as the clients to pay particular attention to children (either explicitly or implicitly) within the rubric of vulnerable groups (ADB, 2009; $\mathrm{AfDB}, 2013 \mathrm{~b}$; $\mathrm{NDB}, 2016$; $\mathrm{WB}, 2016 \mathrm{a}$ ), this does not translate into a recognition of children's participation rights in impact assessment processes. Despite the attention paid to children on 
paper, the lack of explicit MDB engagement with human rights in general and children's rights in particular has meant that children's voices often remain unheard, even when mandatory impact assessments of proposed programmes and projects are conducted. For instance, when the wB and AfDB co-financed the Bujagali Hydropower Project, the lack of a specific children's rights policy meant that children were not included in the consultation processes and their right to be heard was entirely sidestepped for children heading households (Erdem Türkelli, 2020a). Overall, even when children are identified as those likely to be affected by projects, child-friendly modes of participation in consultation or consent processes in terms of accessibility and communication are not envisaged.

The EIB, by virtue of being bound by the EU Charter of Fundamental Rights, has to take into account the protection and care for a child's well-being, the free expression of his/her views, to be 'taken into consideration on matters which concern them in accordance with their age and maturity' and his/her 'best interests [being] a primary consideration' (EU, 20o9: Article 24(1) and (2)). This is essentially a concise restatement of CRC's Articles 3 and 12 which contain, respectively, a focus on children's best interests, participation rights and the right to be heard. Unfortunately, the ЕІв is unique in this respect.

The right to be consulted is complemented by the right to a remedy or redress, given the complexity of many development projects financed by MDBs. Such mechanisms exist in the self-regulatory frameworks of most MDB, including the $\mathrm{ADB}$, the AfDB, the $\mathrm{EIB}$, the IDB, the IFC and the WB beginning with the 199os (Drimmer and LaPlante, 2015).

The World Bank's new safeguards establish a borrower obligation to provide an effective project grievance mechanism and creates the new WB's corporate Grievance Redress Service. The new safeguards thus introduce intermediary remediation mechanisms and foresees the use of these project grievance mechanisms, local grievance mechanisms and the Grievance Redress Service and their exhaustion as requisite steps before being able to take concerns directly to the Inspection Panel (WB, 2016a). The role of the Inspection Panel in addressing management performance and compliance with the Wв safeguard policies remains pivotal and is yet to be tested with respect to the new шв Directive Addressing Risks and Impacts on Disadvantaged or Vulnerable Individuals or Groups (Erdem Türkelli, 2020b). In addition, the w has launched a process for the review of the Inspection Panel as well as the Compliance Advisor/Ombudsman of the IFC. As the first of its kind, the WB Inspection Panel has fallen behind the grievance mechanisms of most other MDBs established later, particularly because it lacks a mandate to monitor and to resolve disputes after it publishes its findings (Van Putten, 2019). Yet, it is 
crucially important for rights-holders to have - at the very least - independent grievance and dispute resolution mechanisms when they are affected by development projects:

Dispute resolution, or mediation, is a voluntary process that when done well can restore communication and trust between parties and result in durable solutions. To be successful, you need an independent, trusted, and professional body to run the process, ensuring a safe space for dialogue. Dispute resolution is distinct from a process in which the bank itself proposes solutions to affected community members-a function currently fulfilled [at the wB] by the Grievance Redress Service. Instead, dispute resolution facilitates a dialogue between the people who will be living with and operating the project long after the bank is gone.

(VAN PUTTEN, 2019)

Of course, even in the presence of credible, independent and effective dispute resolution and grievance mechanisms, accessibility of such mechanisms for all the members of the affected community is a point that too often gets overlooked. On the whole, MDB grievance mechanisms do not offer child-friendly processes or procedures. Children often depend on adults to bring grievances forward. Even the information on the existence of such grievance mechanisms is usually not accessible or advertised to children in any concrete way, in effect curtailing children's rights of access to information. In addition, a survey of the debates around the review and modernisation of such mechanisms, demonstrates that rendering them more child-friendly or child-accessible is not as of yet on the table.

\section{Looking Forward: Filling the Gaps}

Children are often portrayed as the future, embodying the potential of human kind. In global visions on sustainable development such as the one embodied in the 2030 Agenda, children are referenced with respect to their growth potential. The ideal world is one 'which invests in its children and in which every child grows up free from violence and exploitation' (UNGA, 2015: para 8). In economic terms, especially in the business and human rights discourse that tries to make a "business case" for children's rights, children are seen as future employees, employers and entrepreneurs (UNICEF et al., 2012). Yet, when children come face to face with the impacts of policies, programmes and projects 
seeking to enhance economic development, they are too often not designated a rights-holder or a stakeholder status a priori.

The prospective policy engagement of MDBs in enhancing sustainable development and of states in providing the conditions appropriate for children to grow up with full access to the entire spectrum of their rights, free from violence and exploitation should translate themselves into concrete measures. As explored in this article, the CRC Committee has engaged in the interpretation of the substantive provisions of the CRC with respect also to the impact that international organisations, including MDBs, may have on the enjoyment of these substantive provisions. The CESCR has also provided guidance to MDB S with respect to operations and decisions with impacts on economic, social and cultural rights. Three concrete measures as children's rights-friendly policy recommendations may be envisaged in this respect. First, self-regulatory frameworks of MDB s should actively incorporate human rights duties. Second, self-regulation with respect to children and their rights should extend beyond the limited scope of child labour. Third, children should be considered active agents and given the rights and the consideration commensurate with their agency.

\subsection{Active Incorporation of Human Rights Duties in Self-regulatory Frameworks}

The limitations inherent in MDB self-regulatory frameworks can be mostly traced, as explored in this article, to a lack of mandatory and explicit engagement with human rights beyond limited protections for indigenous peoples' rights and labour law protections. Human rights accountability gaps arising from the policies and the activities of MDBs have been widely and accurately portrayed in literature, especially with respect to the Bretton Woods Institutions (the World Bank Group and the International Monetary Fund) (Rich, 1994; Skogly, 2001; Clark, 2002; Alston and Robinson, 2005; Ghazi Shariat Panahi, 2005; Abouharb and Cingranelli, 2006; Darrow, 2006; Hunter, 2010; Narula, 2012; Van Genugten, 2015). The push from parts of civil society and academia to incorporate human rights more directly and in an operational way in the safeguards of MDBs has thus far met with resistance or inaction (Bretton Woods Project, 2018). Nonetheless, public regulators increasingly understand that MDBs cannot function free from social and environmental concerns. While this understanding does not adequately address the various human rights dimensions of financing private investment, there is budding recognition that ' ... MDBs also have a[nother] important role: making sure that the investment benefits the country and its citizens' and such may include 'environmental standards, social considerations' in addition to 
traditional "good governance" measures aimed at making developing countries more investment-friendly (Regling, 2019).

The calls to devote more financing to development continue to intensify as figures released by various institutions put the estimates between 3.3 to 4.5 trillion USD per year of total financing needed to achieve the SDG s by 2030 (UN Doco and Dan Hammarskjöld Foundation, 2018) with "low income developing countries" needing an additional spending of 0.5 Trillion USD in 2030 and "emerging market economies" needing an additional 2.1 Trillion USD of spending (Gaspar et al., 2019). MDBs have been designated a central role in making development projects "bankable":

What we hear when we meet investors is clear: private investors lack 'bankable projects'. Bankable in the sense that they expect their financing to be repaid with adequate return. It is the job of MDBs to help countries unlock, leverage and catalyse private sector finance for investment.

(REGLING, 2019)

MDB s, themselves, have jointly accepted a role in 'increase[ing] private investors' appetite for long term sustainable investments' by 'identify[ing] and structur[ing] sound projects, remov[ing] barriers to investments by means of a more effective investment framework, creat[ing[the appropriate business environment for constructors and operators, and develop[ing] appropriate risk mitigation instruments' (AIIB et al., 2017: 1). It will be increasingly visible that issues within the business - human rights/children's rights nexus are entangled with and cannot be thought separately from human rights and children's rights concerns around how investment is financed and rolled out (Erdem Türkelli, 2020a). It is all the more crucial to ensure that safeguards and regulations governing $\mathrm{MDB}$ s incorporate human rights duties as a groundwork for accountability in light of the calls for greater MD в financing engagement in policy frameworks and investment projects to promote development.

\subsection{Engaging with Children beyond Child Labour}

MDBs' engagement with children and their rights is often confined to the prohibition of hazardous and exploitative forms of child labour. Moving beyond this limited focus may be met with resistance. For instance, when civil society organisations urged the шв to adopt child safeguard measures during the review of its safeguards, these calls largely went unheeded. In the rare instance, children's rights beyond a specific accent to child labour or to vulnerability may be considered. EIB's ESPS are, for instance, much more comprehensive in their engagement with children and their rights. First, in line with the 'due 
deference to parents' invoked under Article 5 CRC that should accompany children's rights (Tobin, 2011), impacts on parents' aspirations about their children's future are included within a broader definition of social impact (EIB, 2009: 7). In addition, EIB's Standard 6 on Involuntary Resettlement requires that children's specific needs be taken into account in ensuring that housing provided after resettlement is accessible (EIB, 2009). In addition, borrowers running projects are required to provide resettlement assistance that ensures affected persons or groups have 'safe and secure access' to 'education for children and childcare facilities' in addition to other services and necessities. (EIB, 2009: 58, para. 48).

When children were consulted by a civil society organisation on the wB safeguard review process involved, some key insights came from children themselves, such as the need to disaggregate a project's social impacts on children and adults, the importance of protecting children's interests and particularly their right to education when communities have to be involuntarily resettled, the need for consultation with children prior to initiating projects as well as for taking such consultations and children's opinions seriously (BIC, 2013). Clearly, children are able to recognise the multifaceted impacts of $\mathrm{MDB}$-financed projects, programmes and policies on their lives and rights, and articulate their demands accordingly. Existing frameworks, however, fail to respond to children's concerns and claims, effectively by failing to give them an adequate voice.

The CRC already places obligations on states parties fully to implement children's right to the enjoyment of the highest attainable standard of health (Article 24), take appropriate measures to assist children's parents or caregivers in implementing the right of every child to an adequate standard of living (Article 27) as well as progressively to realise the right to education on the basis of equal opportunity (Article 28). When such and other rights fall within the scope of MDB projects or programmes or are adversely impacted by the latter, obligations do not become moot.

A deeper and more comprehensive engagement with children and their rights beyond the prohibition of child labour is sorely needed and timely, especially in light of children's intensifying calls to have a say in global policy-making on development, as evidenced by children's ongoing school strikes (supported and joined by adults) in response to the climate emergency and children's demand for accountability from policy-makers in terms of environmental, social and economic policy that will determine the wellbeing of the planet and its inhabitants, including children. In fact, during civil society consultations on the шв safeguards review, children expressed their desire for the Bank to invest in renewable energy sources and protect the natural 
environment, including land, forests and water (BIC, 2013). How and through which means development is financed has a direct bearing on the environmental, social and economic outcomes that impact children's livelihoods, wellbeing and rights. When such decisions are made, rolled-out and implemented, children's voices should be among those heard and their rights, among those that are respected and protected.

\subsection{Considering Children as Active Agents}

Much of the мDв discourse on children in the context of environmental and social safeguards is on children as a vulnerable group. This approach curtails engagement with children as active agents in their own right. The discourse permeates all aspects of practice with regards to self-regulatory norms from overlooking children when communicating information to affected communities about projects and programmes to excluding them from consultation processes and from access to redress mechanisms. On the other hand, there are already policies and mechanisms in place to ensure a measure of access to information, to meaningful consultation and redress in most MDB frameworks. Children are excluded by virtue of their politi$\mathrm{cal}$ and legal voicelessness, because they are often not guaranteed the legal capacity to bring claims directly or to vote in the election of their political representatives (Wall, 2014). Many jurisdictions only allow children to voice their concerns and claims through the proxy of legal representatives. The result is that children are not considered a stakeholder group and end up being excluded from processes such as consultations that seek to mitigate risk. Nonetheless, children should be considered important stakeholders and active agents in any development financing venture, whether policy and project-based.

Teleologically interpreting Article 12.2 of the CRC makes it clear that children should be given the opportunity to have their voices heard not only in judicial proceedings but administrative processes that affect them. They should be allowed access to such processes 'either directly, or through a representative or an appropriate body' (UN, 1989: Article 12.2). Needless to say, in order for children to be able to participate, they should be able to access relevant information from a diversity of sources in line with Article 17 of the CRC. This means, at an operational level, that $\mathrm{MDB}$ s and their clients or borrowers should reach out to children in affected or stakeholder communities when undertaking social and environmental impact assessments and drafting project plans prior to making financing decisions. This engagement should cover not only possible impacts of involuntary resettlement and displacement, for instance, but all relevant aspects of the project that may bear on children's wellbeing and rights. 
The commitment to children's rights should continue throughout the project or programme cycles and also translate into evaluations after the completion of said cycles to identify shortcomings to be remedied, areas of improvement as well as best practices.

\section{Conclusions}

Children, who make up a significant part of the world population, and their rights should be a requisite part of any discussion on how sustainable development is to be governed globally, including how it is to be financed. MDBs, which have been at the centre of financing development since the end of World War II, can and do impact on children's rights when funding development policies and programmes and finance investment projects. While these impacts can be positive, examples of how such impacts have undermined children's rights and jeopardised children's wellbeing abound. The absence of effective frameworks internal to MDBs as well as externally under domestic and international law to regulate MDB interactions with individual and collective rights-holders, including children, has been at the heart of this accountability deficit. While most MDBs have self-regulatory norms that entail special protections for indigenous peoples, attention to so-called "disadvantaged or vulnerable" groups, limited consultation and consent requirements, these norms do not extend to an explicit and mandatory engagement with human rights. Children and their rights are only explicitly protected against economic exploitation in the form of hazardous labour and children are subsumed into a broader group of vulnerable persons. Children's participation rights, on the other hand, are not explicitly recognised even when children are recognised as being affected by a project or a programme.

Despite the absence of protections for their rights from mechanisms regulating how development is financed through MD в s, children are claiming their agency to be included in policy-making on sustainable development in other areas. Particularly in response to the climate emergency, children are demanding to be recognised as a voice integral to how future policy around sustainability is made and implemented. If sustainable development is to be inclusive of children's interests and voices, including in how it is financed and rolled out, MDB s should take their cue from the CRC, which recognises the diversity of children's rights duty-bearers. Consequently, MDB s should actively incorporate human rights duties in their self-regulatory frameworks, engage with children's rights beyond child labour, and consider children as active agents with important participation rights. 
Finally, attention to children's rights policy frameworks should be complemented by a research agenda that puts children's agency and voices at the centre. Despite the interest of a rather small number of civil society actors in guaranteeing children's rights when development is financed, scholarly engagement has hitherto remained scarce. The debates within the broader human rights field that have taken place over the last quarter century on the obligations of international financial institutions (Bradlow, 1996; De Feyter, 2004; Skogly, 2001; Skogly, 2003; Van Genugten, 2015) do not systematically address children's rights concerns. There is a clear need for children's rights scholarship to engage with different international economic actors that affect children's real-life experiences and the realisation of their rights. MDBs, which lead the development financing arena by incentivising public and private actors in policy-making and investment projects, should be a focal point of inquiry going forward.

\section{References}

Abouharb, M.R. and Cingranelli, D.L., "The Human Rights Effects of World Bank Structural Adjustment, 1981-20oo" International Studies Quarterly 2006 (5o(2)) 233-262.

Abouharb, M.R. and Cingranelli, D.L., Human Rights and Structural Adjustment (Cambridge: Cambridge University Press, 2007).

ActionAid International et al., "An open letter to the World Bank and its donors", October 2019: https://www-cdn.oxfam.org/s3fs-public/letter_world_bank_october_2019.pdf. Last accessed: 20 April 2020.

African Development Bank (AfDB), Private Sector Development Policy of the AfDB Group, 2013 (a).

African Development Bank (AfDB), AfDB Group's Integrated Safeguards System: Policy Statement and Operational Safeguards, $2013(\mathrm{~b})$.

African Development Bank (AfDB), Agreement Establishing the African Development Bank (Amended), 2016.

Alston, P., "The World Bank as a Human Rights-Free Zone" in, F. Lafontaine and F. Larocque (eds.), Doing Peace the Rights Way: Essays in International Law and Relations in Honour of Louise Arbour (Antwerp: Intersentia, 2019).

Alston, P. and Robinson, M. (eds), Human Rights and Development: towards mutual reinforcement (Oxford: Oxford University Press, 2005). DOI:10.1093/acprof: oso/9780199284627.001.0oo1.

Alston, P. and Tobin, J. (with the assistance of Darrow, M.), Laying the Foundations for Children's Rights: An Independent Study of some Key Legal and Institutional Aspects of 
the Impact of the Convention on the Rights of the Child (Florence: UNICEF Innocenti Insight, 2005).

Asian Development Bank (ADB), Agreement Establishing the Asian Development Bank (Amended), 1994.

Asian Development Bank (AD B), Safeguard Policy Statement, June 2009.

Asian Development Bank (АDB), Nenskra Hydropower Project Supplementary Environmental \& Social Studies Volume 3 Social Impact Assessment, November 2017.

Asian Development Bank (ADB), Report of the Board Compliance Review Committee and Compliance Review Panel's Report on Eligibility of the Compliance Review Request for Project Number 49223-oor Nenskra Hydropower Project (Georgia), 7 March 2018.

Asian Infrastructure Investment Bank (AIIB), Articles of Agreement, 2015.

Asian Infrastructure Investment Bank (АІІB), Environmental and Social Framework, February 2016.

Asian Infrastructure Investment Bank (АІІ В) et al., Joint mdb Statement of Ambitions for Crowding in Private Finance, 2017: ttps://www.bundesfinanzministerium.de/ Content/DE/Downloads/G2o-Dokumente/Hamburg_Genannte_Berichte/JointMDB-Statement-of-Ambitions.pdf?_blob=publicationFile\&v=1. Last accessed 4 October 2019 .

Bank Information Center (BIC), Children's Voices on wb Safeguards, BIC, 2013.

Bank Information Center (BIC) and the Human Rights Society of Uzbekistan (Ezgulik), The Need for Child Impact Assessments: A Case Study of the International Development Association Funded Uzbekistan Rural Enterprise Support Project-Phase ii, April 2013.

Bradlow, D.D., "The World Bank, the IMF, and human rights", Transnational Law and Contemporary Problems 1996 (6) 47-9o.

Bretton Woods Project, Civil society apprehensive as World Bank launches new Environmental and Social Framework, 6 December 2018: https://www. brettonwoodsproject.org/2018/12/civil-society-apprehensive-as-world-banklaunches-new-environmental-and-social-framework/. Last accessed 4 October 2019.

Cissé, H., "Should the Political Prohibition in Charters of International Financial Institutions Be Revisited? The Case of the World Bank", in , H. Cissé , D. Bradlow and , B. Kingsbury (eds.), The World Bank Legal Review: Law, International Financial Institutions and Global Legal Governance, Vol. 3 (Washington D.C.: World Bank, 2011), 59-92.

Clark, D.L., "World Bank and Human Rights: The Need for Greater Accountability", 15 Harvard Human Rights Journal 2002 (15) 205-226.

Committee on Economic, Social and Cultural Rights (CEscr), General Comment No. 14 on the Right to the Highest Attainable Standard of Health, E/C.12/200o/4, 11 August 2000. 
Committee on Economic, Social and Cultural Rights (CESCR), General Comment No. 15 on the Right to Water, E/C.12/2002/1, 2002.

Committee on the Rights of the Child (CrC Committee), GC 16 on State obligations regarding the impact of the business sector on children's rights, CRC/C/GC/16, 17 April 2013.

Committee on the Rights of the Child (CRC Committee), GC 19 on public budgeting for the realization of children's rights (art. 4), CRC/C/GC/19, 20 July 2016.

Dann, P. and Riegner, M., "The World Bank's Environmental and Social Safeguards and the evolution of global order", Leiden Journal of International Law 2019 (32), 537-559.

Darrow, M., Between light and shadow: the World Bank, the International Monetary Fund and international human rights law (Oxford: Hart Publishing, 2006).

De Feyter, K., "International financial institutions and human rights: Law and practice", Human Rights Review, Vol. 6, 56-9o, 2004.

Drimmer, J. and Laplante, L.J., "The Third Pillar", in, J. Martin and, K.E. Bravo (eds), The Business and Human Rights Landscape: Moving Forward, Looking Back (Cambridge: Cambridge University Press, 2015), 316-347.

Erdem Türkelli, G., Children's Rights and Business: Governing Obligations and Responsibility (Cambridge: Cambridge University Press, 2020a).

Erdem Türkelli, G., "The Best of Both Worlds or the Worst of Both Worlds? Multilateral Development Banks, Immunities and Accountability to Rights-Holders", The Hague Journal on the Rule of Law, 6 April 2020b. DOI: https://doi.org/10.1007/ s40803-02O-00143-1.

European Bank for Reconstruction and Development (EBRD), “ Environmental and Social Policy" (ESP), May 2014.

European Development Finance Institutions (EDFI), "Harmonized EDFI Exclusion List", September 2011.

European Investment Bank (Е IB), "Statement of Environmental and Social Principles and Standards (ESPS) ", 2009: http://www.eib.org/attachments/strategies/eib_ statement_esps_en.pdf. Last accessed 4 October 2019.

European Investment Bank (ЕIB), Complaints Mechanism, Olkaria I and IV Kenya Complaint sG/E/2014/o7 Complaint SG/E/2014/o8: Conclusions Report, 11 November 2015: https://www.eib.org/attachments/complaints/sg-e-2014-o7ando8-conclusions-report-en.pdf. Last accessed 20 April 2020.

European Union (EU), The Charter of Fundamental Rights of The European Union (2000/C 364/o1), C 364/14 Official Journal of the European Communities, 18 December 2000 .

Gaspar, V. et al., Fiscal Policy and Development: Human, Social, and Physical Investments for the SDGs (Washington, D.C.: IMF, 2019).

Ghazi Shariat Panahi, B., The IMF, the World Bank group, and the question of human rights (Ardsley, N.Y.: Transnational Publishers, 2005). 
Himberg, H., "Comparative Review of Multilateral Development Bank Safeguard Systems: Main Report and Annexes", World Bank, May 2015: https://consultations. worldbank.org/Data/hub/files/consultation-template/review-and-update-worldbank-safeguard-policies/en/phases/mdb_safeguard_comparison_main_report_ and_annexes_may_2015.pdf. Last accessed 4 October 2019 .

Human Rights Watch (HRW), "Letter to the ADB President Mr. Takehiko Nakao: Concerns Regarding Forced Labor in the Modernization and Improved Performance of the Amu Bukhara Irrigation System (ABIS) Project in Uzbekistan", 3 September 2013.

Hunter, D.B., International Financial Institutions and International Law (Alphen aan den Rijn, the Netherlands: Kluwer Law International, 2010).

Inter-American Development Bank (IDB), Agreement Establishing the Inter-American Development Bank (Amended), 1996.

Inter-American Development Bank (IDB), Involuntary Resettlement in IDB, Projects: Principles and Guidelines, November 1999.

Inter-American Development Bank (IDB), Environment and Safeguards Compliance Policy, 19 January 2006(a).

Inter-American Development Bank (IDB), Operational Policy on Indigenous Peoples and Strategy for Indigenous Development, July 2006(b).

Inter-American Development Bank (IDB), ID B, Exclusion List - Non-Sovereign Guaranteed Operations and Trade Finance Operations, 2006(c): https://indesvirtual. iadb.org/pluginfile.php/40739/mod_resource/content/o/recursos/EN/M2/ exclusion_list.pdf. Last accessed 4 October 2019.

International Bank for Reconstruction and Development (I B RD), Articles of Agreement (Amended), 27 December 2012.

International Commission of Jurists (ICJ), ICJ, Financial Institutions and the Rights of the Child: An Overview of Policies and Accountability Mechanisms (Geneva: ICJ, 2014): https://www.icj.org/new-icj-report-financial-institutions-and-the-rights-ofthe-child/. Last accessed 20 April 2020.

International Development Association (IDA), Articles of Agreement, 196o. International Finance Corporation (IFC), IFC Project Exclusion List, 2007.

International Finance Corporation (IFC), International Finance Institutions (IFIs) and Development Through the Private Sector (Washington D.C.: IFC, 2011).

International Finance Corporation (IFC), IFC Sustainability Framework: Policy and Performance Standards on Environmental and Social Sustainability and Access to Information Policy, 1 January $2012(\mathrm{a})$.

International Finance Corporation (IFC), Articles of Agreement (Amended), 27 December 2012(b).

International Finance Corporation (IFC), IFC response to the Cotton Campaign, December 2015: http://www.cottoncampaign.org/uploads/3/9/4/7/39474145/ifc_ response_cottoncampaign_december2o15.pdf. Last accessed 4 October 2019. 
Joy for Children, Uganda and Bank Information Center (BIC), The Impact of the World Bank Funded Kamwenge - Kabarole Road Construction Project on Children, April 2015: http://www.bankinformationcenter.org/wp-content/uploads/2015/o4/ Kamwenge-Road-Final.pdf. Last accessed 4 October 2019.

Klees, J.S. et al., "Conclusions" in J.S. Klees et al., The World Bank and Education: Critiques and Alternatives (Rotterdam: Sense Publishers, 2012).

Koissaba, B.R.O., Geothermal Energy and Indigenous Communities: The Olkaria Projects in Kenya (Heinrich Böll Stiftung European Union, 2018): https://eu.boell.org/sites/ default/files/geothermal-energy-and-indigenous-communities-olkariaprojectkenya.pdf. Last accessed 20 April 2020.

Lesotho National Federation of Organisations of the Disabled, Lesotho Quality Education For Equality (Monitoring) Report, 26 February 2018: https:// bankinformationcenter.cdn.prismic.io/bankinformationcenter\%2F $534 \mathrm{f} 6 \mathrm{a} 66$-o2d24ebd-985b-86301b87a3f5_final+lesotho+interim+report+march+2o18-share.pdf. Last accessed 20 April 2020.

Malouf Bous, K. and Farr, J., False promises: How delivering education through publicprivate partnerships risks fueling inequality instead of achieving quality education for all (Oxford: Oxfam, 2019).

Malpass, D., Letter from World Bank Group President David Malpass to Treasury Secretary Mnuchin, 20 March 2020: https://financialservices.house.gov/ uploadedfiles/malpass_ltr_mnuchin_3202020.pdf. Last accessed 20 April 2020.

Nampungu, P. and Kasabiiti, D., The Impact of Involuntary Resettlement on Children A Case Study of the International Development Association Funded Bujagali HydroPower Dam - Naminya Resettlement Area (Washington, D.C.: BIC, 2012).

Narula, S., "International Financial Institutions, Transnational Corporations and Duties of States" in , M. Langford et al., Global Justice, State Duties: The Extraterritorial Scope of Economic, Social, and Cultural Rights in International Law (Cambridge: Cambridge University Press, 2012).

New Development Bank (NDB), Agreement on the New Development Bank, 2015.

New Development Bank (NDB), Environment and Social Framework Overview, 11 March 2016.

Palacio, A., "The Way Forward: Human Rights and the World Bank"', World Bank Website, October 20o6: http://web.worldbank.org/WBSITE/EXTERNAL/TOPICS/ EXTLAWJUSTICE/o,,contentMDK:21106614 menuPK:445673 pagePK:64020865 piPK:149114 theSitePK:445634,oo.html. Last accessed 4 October 2019.

Regling, K., 'Speech: "The Role of Multilateral Development Banks in mobilising private capital", 2019 Annual Meeting of the Asian Infrastructure Investment Bank", Luxembourg, 12 July 2019: https://www.esm.europa.eu/speeches-andpresentations/role-multilateral-development-banks-mobilising-private-capital. Last accessed 4 October 2019. 
Rich, B., Mortgaging the Earth: The World Bank, environmental impoverishment, and the crisis of development (Boston: Beacon Press 1994). DOI: 10.1002/sd.3460030309.

Sarfaty, G., "Why Culture Matters in International Institutions: The Marginality of Human Rights at the World Bank", American Journal of International Law 2009 (103(4)), 647-683. DOI: 10.1017/Sooo2930ooo15981o.

Shihata, I.E.I., "The World Bank's protection and promotion of children's rights", The International Journal of Children's Rights 1996 (4), 383-406. DOI: 10.1163/157181896Xooo40.

Skogly, S., Human Rights Obligations of the World Bank and the IMF (London: Cavendish Publishing: 2001).

Skogly, S., "The human rights obligations of the World Bank and IMF", in , W. Van Genugten et al. (eds.), World Bank, IMF and Human Rights (Nijmegen: Wolf Legal Publishers 2003).

Third International Conference on Financing for Development, Addis Ababa Action Agenda, 2015.

Tobin, J., "Understanding a Human Rights Based Approach to Matters Involving Children: Conceptual Foundations and Strategic Considerations", in , A. Invernizzi and , J. Williams (eds.), The Human Rights of Children (Farnham: Ashgate 2011).

Ul Haq, M., Reflections on Human Development (New York: Oxford University Press 1995).

UNICEF, Save the Children and UN Global Compact, Children's Rights and Business Principles, 2012.

United Nations (UN), The Convention on the Rights of the Child, 1989.

United Nations Development Operations Coordination Office (UN Doco) and Dan Hammarskjöld Foundation, Unlocking SDG Financing: Findings from Early Adopters (New York: UNSDG, 2018).

United Nations Development Programme (UNDP), Human Development Report 1995 (New York: Oxford University Press, 1995).

United Nations General Assembly (UNGA), Transforming our world: the 2030 Agenda for Sustainable Development, A/RES/70/1, 21 October 2015.

United Nations General Assembly (UNGA), Report of the Independent Expert on the effects of foreign debt and other international financial obligations of States on the full enjoyment of all human rights, particularly economic, social and cultural rights (main focus: responsibility for complicity of ifis in human rights violations in the context of retrogressive economic reforms), A/74/178, 16 July 2019.

United Nations (UN) Human Rights Council, Resolution 34/16: Rights of the child: protection of the rights of the child in the implementation of the 2030 Agenda for Sustainable Development, A/HRC/34/L.25. Adopted as orally revised without a vote, 57th meeting, 24 March 2017. 
Vandenhole, W. et al., Children's Rights: A Commentary on the Convention on the Rights of the Child and its Protocols (Cheltenham: Edward Elgar, 2019).

Van Genugten, W., The World Bank Group, the IMF and Human Rights: A Contextualised Way Forward (Antwerp: Intersentia, 2015). DOI: 10.1017/9781780685649.

Van Putten, M., "Opinion: It's time to revive the spirit of accountability at the World Bank", DEVEX.com, 1 October 2019: https://www.devex.com/news/opinion-it-stime-to-revive-the-spirit-of-accountability-at-the-world-bank-95714. Last accessed 4 October 2019 .

Wachenfeld, M., "The hidden impacts of large infrastructure projects on children", The Guardian, 3 May 2012: http://www.theguardian.com/sustainable-business/ children-large-infrastructure-honeypot-effect. Last accessed 4 October 2019.

Wall, J., "Why Children and Youth Should Have the Right to Vote: An Argument for Proxy-Claim Suffrage", Children, Youth and Environments 2014 (24(1)), 108-123. DOI: 10.7721/chilyoutenvi.24.1.0108.

World Bank (WB), Project Appraisal Document (PAD) on a Proposed Grant in the Amount of SDR 33.1million (US $\$ 50$ Million Equivalent) to the DRC (DRC) for A Growth with Governance in the Mineral Sector Technical Assistance Project (Report No: 53116-ZR), 19 May 2010.

World Bank (WB), Environmental and Social Framework Setting Environmental and Social Standards for Investment Project Financing (ESF), 4 August 2016(a).

World Bank (WB) Inspection Panel, Transport Sector Development Project - Additional Financing (P121097): Investigation Report, 4 August 2016.

World Bank( (шв), Directive Addressing Risks and Impacts on Disadvantaged or Vulnerable Individuals or Groups (Directive on Disadvantaged/Vulnerable Individuals/Groups), 4 August 2016(b): https://ppfdocuments.azureedge.net/e5562765-a553-4eao-b7877e1e 775 f29d5.pdf. Last accessed 4 October 2019.

World Bank(WB), Environmentaland Social Policy for InvestmentProject Financing (IPF), 2018.

World Bank (wв ), Implementation Completion and Results Report IDA H589o Tfio744 on a Grant in the Amount of $\operatorname{sdr} 33.1$ Million (US\$50 Million Equivalent) to The Democratic Republic of Congo for the Growth with Governance In the Mineral Sector (P1o6982), April 18, 2019(a).

World Bank(wв), Projectata Glance:DRC-Growthwith Governance in the Mineral Sector Project: http://www.worldbank.org/projects/P106982?lang=en\&tab=overview, 2019. Last accessed 4 October 2019 (b). 